Pemahaman Mengenai Undang-Undang Dan Etika

Profesi Akuntan Publik Terhadap Pemilihan Karier

Sebagai Akuntan Publik

ISSN : 2477-6157

\title{
PEMAHAMAN MENGENAI UNDANG-UNDANG DAN ETIKA PROFESI AKUNTAN PUBLIK TERHADAP PEMILIHAN KARIER SEBAGAI AKUNTAN PUBLIK
}

\author{
Dita Ristya Damawati, Endang Masitoh Wahyuningsih, Yuli Chomsatu Samrotun \\ Universitas Islam Batik Surakarta \\ Email : tharistya@yahoo.co.id
}

\begin{abstract}
This research aim to know partially and simultaneously influence the understanding of the laws and ethics of the public accounting profession for a career as a public accountant election. This type of research is qualitative descriptive. The data source is the primary data. Population, sample and respondents were accounting students UNIBA Surakarta, sampling with random sampling. The research instrument used questionnaires in the validity and reliability. Data analysis method used descriptive test, classic assumption test including normality test, multicolinearity test, heteroscedasticity test, autocorrelation test for hypothesis testing using multiple linear regression with $t$ test, $F$ test and test determiasi $\left(R^{2}\right) . H_{1}$ result $t$ count $>$ t table $(3.591>1.991)$, and the significance $0.001<0.05$ so $H_{a}$ is received, so the understanding of the laws public accountant influence on the selection of a career as a public accountant. $\mathrm{H}_{2}$ result $t$ count $>t$ table $(2.054>1.991)$, and the significance $0.043<0.05$ so $H_{a}$ is received, so the understanding of the public accounting profession ethics influence the election of a career as a public accountant. Test $F, F$ count $>F$ table $(13.543>3.115)$ and significance $<0.05(0.000<0.05)$, the $H_{a}$ received so $\mathrm{H}_{3}$ result is that an understanding of the laws and ethics of the public accounting profession simultaneously affect the election as $a$ career public accountant.
\end{abstract}

Key words: Law, Public Accountant, Professional Ethics, Career Selection. 


\section{PENDAHULUAN}

\section{A. Latar Belakang Masalah}

Sejalan dengan perkembangan perusahaan di Indonesia, profesi akuntan publik mulai berkembang juga. Tetapi jumlah akuntan publik tidak sebanding dengan penduduk di Indonesia yang laju pertumbuhannya semakin padat. Maka, menjadi seorang akuntan publik seharusnya menjadi salah satu pilihan karier yang utama bagi mahasiswa jurusan akuntansi, karena profesi akuntan publik masih sangat dibutuhkan di Indonesia. Namun banyak mahasiswa akuntansi yang masih banyak belum tertarik akan profesi akuntan publik dikarenakan mereka merasa persyaratan untuk menjadi seorang akuntan publik sangatlah lama dan membosankan. Untuk menjadi seorang akuntan publik seseorang harus mendapat gelar sarjana ekonomi terlebih dahulu selama empat atau bahkan lima tahun. Kemudian mereka harus mengambil Pendidikan Profesi Akuntan Publik selama dua tahun, lalu harus mempunyai pengalaman dalam praktek sebagai Akuntan Publik, setelah itu mengajukan permohonan kepada Menteri Keuangan agar mendapatkan ijin menjadi seorang akuntan publik.

Akuntan publik adalah akuntan yang memberikan jasa pelayanan akuntansi kepada masyarakat/akuntan yang memiliki ijin dari pihak yang berwenang untuk membuka kantor akuntan swasta. Istilah akuntan publik merupakan ungkapan resmi dalam Bahasa Indonesia. Jasa disini bermaksud jasa asurance yang meliputi jasa audit atas informasi keuangan historis, jasa review atas keuangan historis, dan jasa asuransi lainnya. Selain jasa asurance, akuntan publik juga memberikan jasa lainnya yang berhubungan dengan akuntansi, keuangan, dan manajemen sesuai dengan perundang-undangan yang berlaku. Sedangkan dalam Keputusan Menteri Keuangan Republik Indonesia (Nomor: 43/KMK.017/1997; Bab I; Pasal 1; Poin a), dinyatakan bahwa : akuntan publik adalah akuntan yang memiliki izin dari menteri keuangan untuk menjalankan pekerjaan akuntan publik. Dengan demikian, dapat disimpulkan bahwa akuntan publik merupakan seorang akuntan yang telah menempuh dan lulus Ujian Sertifikasi Akuntan Publik, memenuhi persyaratan profesional untuk menjadi akuntan publik, dan telah mendapatkan izin dari menteri keuangan untuk menjalankan pekerjaan akuntan publik. Berdasarkan paparan yang dikemukakan diatas, maka penulis akan melakukan penelitian dengan judul "PEMAHAMAN MENGENAI UNDANG - UNDANG DAN ETIKA PROFESI AKUNTAN PUBLIK TERHADAP PEMILIHAN KARIER SEBAGAI AKUNTAN PUBLIK".

\section{B. Perumusan Masalah}

Adapun pokok permasalahan yang akan dirumuskan dalam penelitian ini, sebagai berikut

1. Apakah pemahaman mengenai UndangUndang akuntan publik berpengaruh terhadap pemilihan karier sebagai akuntan publik?

2. Apakah pemahaman mengenai etika profesi akuntan publik berpengaruh terhadap pemilihan karier sebagai akuntan publik?

3. Apakah pemahaman mengenai UndangUndang dan etika profesi akuntan publik secara simultan berpengaruh terhadap pemilihan karier sebagai akuntan publik?

\section{Tujuan Penelitian} berikut :

Tujuan penelitian dapat dijelaskan sebagai

1. Untuk mengetahui pengaruh pemahaman mengenai Undang-Undang akuntan publik terhadap pemilihan karier sebagai akuntan publik.

2. Untuk mengetahui pengaruh pemahaman mengenai etika profesi akuntan publik terhadap pemilihan karier sebagai akuntan publik.

3. Untuk mengetahui pengaruh pemahaman mengenai Undang-Undang akuntan publik dan mengenai etika profesi akuntan publik secara simultan terhadap pemilihan karier sebagai akuntan public 


\section{Manfaat Penelitian}

1. Bagi Peneliti, menambah wawasan peneliti tentang dunia profesi akuntan publik tentang persyaratan, perijinan, fungsinya, wewenangnya, etika dalam menjalankan tugas profesionalnya dan halhal yang penting tentang akuntan publik.

2. Bagi Pembaca, menambah pengetahuan pembaca tentang profesi akuntan publik dan memberi ide pemikiran bagi pihakpihak yang ingin mengetahui lebih lanjut dengan melakukan penelitian tentang akuntan publik.

3. Bagi mahasiswa akuntansi, memberikan dorongan untuk memilih profesi sebagai akuntan publik setelah lulus dari perguruan tinggi.

\section{TINJAUAN PUSTAKA}

\section{A. Landasan Teori}

1. Undang-Undang Akuntan Publik. UndangUndang Akuntan Publik ini, yaitu mengatur mengenai "Jasa Asurance" yang merupakan hak ekslusif bagi Akuntan Publik, yaitu jasa Akuntan Publik yang bertujuan untuk memberikan keyakinan bagi pengguna atas hasil evaluasi atau pengukuran informasi keuangan dan non keuangan berdasarkan suatu kriteria. Selain mengatur mengenai profesi Akuntan Publik, Undang-Undang ini juga mengatur mengenai Kantor Akuntan Publik ( KAP ) yang merupakan wadah bagi Akuntan Publik dan bentuk usaha KAP yang sesuai dengan profesi Akuntan publik, yaitu independensi dan tanggung jawab professional terhadap hasil pekerjaannya. Undang-Undang ini disusun dengan tujuan untuk melindungi kepentingan publik, mendukung perekonomian yang sehat, efisien dan transparan, memelihara integritas profesi akuntan publik, serta melindungi kepentingan profesi akuntan publik sesuai dengan standar dan kode etik profesi

2. Etika Profesi Akuntan Publik. Kode Etik Profesi Akuntan Publik (sebelumnya disebut Aturan Etika Kompartemen Akuntan Publik) adalah aturan etika yang harus diterapkan oleh anggota Institut
Akuntan Publik Indonesia atau IAPI (sebelumnya Ikatan Akuntan Indonesia Kompartemen Akuntan Publik atau IAIKAP) dan staf profesional (baik yang anggota IAPI maupun yang bukan anggota IAPI) yang bekerja pada satu Kantor Akuntan Publik (KAP). Kode Etik Profesi Akuntan Publik (Kode Etik) ini terdiri dari dua bagian, yaitu Bagian A dan Bagian B. Bagian A dari Kode Etik ini menetapkan prinsip dasar etika profesi dan memberikan kerangka konseptual untuk penerapan prinsip tersebut. Bagian B dari Kode Etik ini memberikan ilustrasi mengenai penerapan kerangka konseptual tersebut pada situasi tertentu.

3. Pemilihan karier. Karier adalah suatu rangkaian atau pekerjaan yang dicapai seseorang dalam kurun waktu tertentu yang berkaitan dengan sikap, nilai, perilaku dan motivasi dalam individu. Karier bertujuan untuk mencapai posisi di masa yang akan datang dalam pekerjaan setiap individu. Keberhasilan karir tidak lagi diartikan sebagai penghargaan intitusional dengan meningkatnya kedudukan dalam suatu hirarki formal. Kunci keberhasilan karir pada masa yang akan datang lebih dicerminkan dari pengalaman hidup seseorang daripada posisi yang dimilikinya.

4. Profesi Akuntan Publik. Profesi akuntan publik bertanggung jawab untuk menaikkan tingkat keandalan laporan keuangan perusahaan-perusahaan, sehingga masyarakat keuangan memperoleh informasi keuangan yang andal sebagai dasar untuk memutuskan alokasi sumber-sumber ekonomi.

\section{B. Penelitian Terdahulu}

Penelitian terdahulu yang akan mendasari penelitian yang akan dilakukan peneliti dalam penelitian ini yaitu :

1. Adek Fajar Agustini DS, 2010 dengan judul "Anlisis Faktor-Faktor Yang Mempengaruhi Mahasiswa Akuntansi Di Universitas Pembangunan Nasional Veteran Jatim dalam Pemilihan Profesi Sebagai Akuntan Publik", Berdasarkan 
Pemahaman Mengenai Undang-Undang Dan Etika Profesi Akuntan Publik Terhadap Pemilihan Karier Sebagai Akuntan Publik

hasil analisis regresi logistik menunjukkan bahwa hipotesis ke-1 yang menyatakan "Bahwa faktor nilai intrinsik pekerjaan, gaji, pertimbangan pasar kerja dan persepsi mahasiswa akuntansi tentang profesi akuntan publik berpengaruh terhadap pemilihan profesi akuntan publik bagi mahasiswa akuntansi Universitas Pembangunan Nasional "Veteran" Jawa Timur" tidak teruji kebenarannya. Hipotsis ke-2 yang menyatakan "Bahwa faktor persepsi mahasiswa akuntansi tentang profesi akuntan publik merupakan faktor yang paling dominan berpengaruh terhadap pemilihan profesi akuntan publik bagi mahasiswa akuntansi Universitas Pembangunan Nasional "Veteran" Jawa Timur" tidak teruji kebenarannya.

2. Andreas Sofyan Nainggolan, 2013 dalam judul "Pengaruh Persepsi Mahasiswa Akuntansi Mengenai Undang-Undang Akuntan Publik Dan Etika Profesi Akuntan Publik Terhadap Persepsi Mengenai Pilihan Kariernya Sebagai Akuntan Publik". Berdasarkan hasil pengujian hipotesis dengan menggunakan uji t untuk parsial dan uji $F$ untuk simultan menunjukkan bahwa ada pengaruh persepsi mahasiswa akuntansi tentang Undang-Undang Akuntan Publik dan Etika Profesi Akuntan Publik terhadap persepsi mengenai pilihan kariernya sebagai Akuntan Publik baik secara parsial maupun simultan.

4. Muthia Corawettoeng, 2013 dengan judul "Pengaruh Persepsi Mahasiswa Akuntansi Mengenai Lingkungan Kerja Auditor Terhadap Pilihan Kariernya Sebagai Auditor (Studi Pada Mahasiswa Akuntansi Universitas Hasanudin dan Politehnik Negeri Ujung Pandang)". Dengan hasil pengujian uji $t$ menunjukkan bahwa persepsi mahasiswa akuntansi mengenai lingkungan kerja auditor memiliki pengaruh terhadap pilihan karier sebagai auditor.

\section{Kerangka Pemikiran}

Kerangka pemikiran dalam penelitian ini adalah sebagai berikut :

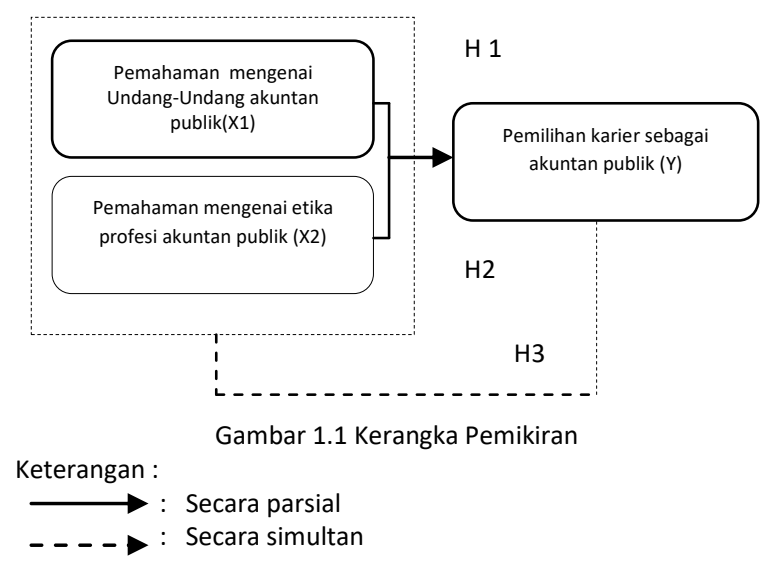

\section{Hipotesis Penelitian}

$\mathrm{H}_{1}$ : Pemahaman mengenai Undang-Undang akuntan publik berpengaruh terhadap pemilihan karier sebagai akuntan publik.

$\mathrm{H}_{2}$ : Pemahaman mengenai etika profesi akuntan publik berpengaruh terhadap pemilihan karier sebagai akuntan publik.

$\mathrm{H}_{3}$ : Pemahaman mengenai Undang-Undang dan etika profesi akuntan publik secara simultan berpengaruh terhadap pemilihan karier sebagai akuntan publik.

\section{METODOLOGI PENELITIAN}

\section{A. Jenis Penelitian}

Jenis penelitian dalam penelitian ini adalah jenis penelitian deskriptif kualitatif karena mendeskripsikan mengenai gambaran umum objek penelitian dan data penelitian berupa angka-angka dengan dianalisis menggunakan uji statistik.

\section{B. Variabel Penelitian dan Pengukuran}

Variabel dalam penelitian ini terdiri dua variabel independen (X) dan satu variabel dependen (Y).

1. Variabel Independen (X)

a. Pemahaman mengenai Undang-Undang akuntan publik $\left(\mathrm{X}_{1}\right)$. Definisi : Perizinan yang terdiri atas persyaratan menjadi akuntan publik, sertifikasi, persyaratan bagi akuntan publik asing untuk bekerja di Indonesia dan sanksi yang terdiri dari sanksi administratif dan sanksi pidana, indikator : Hak Akuntan Publik (imbalan jasa, perlindungan hukum, memperoleh informasi) Kewajiban akuntan publik 
(ikut asosiasi profesi, menjaga kompetensi, berperilaku jujur dan integritas tinggi)Sanki (manipulsi, memalsukan data, tidak membuat kertas kerja, menghambat kelancaran pemeriksaan, tidak memperpanjang ijin.

b. Pemahaman mengenai etika profesi akuntan publik $\left(\mathrm{X}_{2}\right)$. Definisi : Aturan etika yang harus diterapkan oleh anggota Institut Akuntan Publik Indonesia atau IAPI (sebelumnya Ikatan Akuntan Indonesia Kompartemen Akuntan Publik atau IAI-KAP) dan staf profesional (baik yang anggota IAPI maupun yang bukan anggota IAPI) yang bekerja pada satu Kantor Akuntan Publik (KAP). Indikator :Tanggung jawab profesi, kepentingan publik, integritas, obkjektivitas dan kompetensi.

2. Variabel Dependen (Y) Pemilihan karier sebagai akuntan publik. Definisi : Suatu pilihan pekerjaan profesional di bidang akuntansi yang fokus terhadap pengauditan yang jenjang kariernya jelas. Indikator : Keahlian, nilai intrinsik pekerjaan, gaji, lingkungan kerja, pelatihan profesional, pengakuan profesional.

Skala pengukuran ketiga variabel menggunakan skala likert : $1=$ Tidak Setuju , 2= Kurang Setuju, 3= Setuju, 4= Sangat Setuju, 5 = Sangat Setuju Sekali

\section{Sumber Data dan Responden}

Sumber data adalah data primer, karena data diperoleh secara langsung dari jawaban kuesioner. Responden yaitu mahasiswa akuntansi UNIBA Surakarta.

\section{Populasi dan Sampel}

Populasi dalam penelitian ini adalah seluruh mahasiswa akuntansi UNIBA Surakarta yang sudah mengikuti mata kuliah pengauditan 1 dan 2 (semester 5 keatas). Sampel yang diambil 100 mahasiswa dengan menggunakan tehnik random/acak.

\section{E. Instrumen Penelitian}

Instrumen penelitian yang digunakan dalam penelitian ini dengan menggunakan kuesioner. Kuesioner di adopsi dari skripsi Andreas Sofyan Nainggolan, 2013 dalam judul "Pengaruh Persepsi Mahasiswa Akuntansi Mengenai Undang-Undang Akuntan Publik Dan Etika Profesi Akuntan Publik Terhadap Persepsi Mengenai Pilihan Kariernya Sebagai Akuntan Publik. Data yang diperoleh akan diuji dengan uji validitas dan uji reliabilitas. Uji validitas dan uji reliabilitas data digunakan untuk mengukur kualitas data pada setiap pertanyaan atau pernyataan yang mewakili masing-masing variabel. Pertanyaan atau pernyataan yang valid dan reliabel digunakan untuk proses analisis data selanjutnya, dan untuk pertanyaan atau pernyataan yang tidak valid dan tidak reliabel dibuang dan tidak dimasukkan dalam proses analisa data selanjutnya.

1. Uji Validitas

Untuk mengukur validitas item butir pertanyaan dengan tehnik Correted Item Total Correlation, yaitu mengorelasikan antara skor item dengan total item, kemudian melakukan korelasi terhadap nilai koefisien korelasi. Asumsi yang digunakan dalam uji validitas adalah uji signifikansi dilakukan dengan membandingkan nilai $r$ hitung dengan $r$ tabel untuk degree of freedom $(\mathrm{df})=\mathrm{n}-2$, dalam hal ini n adalah jumlah sampel.

2. Uji Reliabilitas

Pengujian reliabilitas dilakukan dengan tehnik Cronbach Alpha untuk mengetahui konsistensi atau keandalan hasil pengukuran suatu instrumen apabila instrumen tersebut digunakan lagi sebagai alat ukur suatu responden. Suatu instrumen dikatakan reliabel jika memiliki nilai Cronbach Alpha lebih besar dari 0,6 (Ghozali, 2005 : 42). Menurut Sekaran (1992) reliabilitas kurang dari 0,6 adalah kurang baik.

\section{F. Metode Analisis Data}

Pengolahan data yang dilakukan oleh peneliti menggunakan program SPSS versi 17. Adapun metode dan langkah-langkah untuk analisis data dalam peneitian ini adalah : 
1. Uji Asumsi Klasik

Uji asumsi klasik dalam penelitian ini adalah, uji normalitas, uji multikolinearitas, uji heteroskedastisitas dan uji autokorelasi.

a. Uji normalitas menggunakan Kolmogorov-Smirnov Test, dengan kriteria pengujian sebagai berikut :

- Signifikansi > 0,05, maka data terdistribusi normal.

- Signifikansi $<0,05$, maka data tidak terdistribusi normal.

b. Uji multikolinearitas dengan melihat nilai tolerance dan inflation factor (VIF) pada model regresi. Variabel yang menyebabkan multikolinearitas dapat dilihat dari nilai tolerance yang lebih kecil daripada 0,1 atau nilai VIF yang lebih besar dari pada nilai 10 (Hair et al. 1992).

c. Uji heteroskedastisitas dilakukan dengan melihat pola titik-titik pada grafik regresi. Kriteria yang menjadi dasar pengambilan keputusan adalah sebagai berikut :

1) Jika ada pola tertentu, seperti titiktitik yang ada membentuk suatu pola tertentu yang teratur (bergelombang, melebar, kemudian menyempit), maka terjadi heteroskedastisitas.

2) Jika tidak ada pola yang jelas, seperti titik-titik menyebar di atas dan di bawah angka 0 pada sumbu Y, maka tidak terjadi heteroskedastisitas.

d. Uji autokorelasi, metode pengujiannya menggunakan uji Durbin-Watson (DW test), yaitu nilai DW dibandingkan dengan DW tabel. Kriteria yang dipakai adalah sebagai berikut:

1) Jika DW < dl atau DW > 4-dl, berarti terdapat autokorelasi.

2) Jika DW terletak antara dU dan 4-dU, berarti tidak ada autokorelasi.

3) Jika DW terletak antara dL dan dU atau diantara 4-dU dan 4-dl, maka tidak menghasilkan kesimpulan yang pasti.

\section{Uji Hipotesis}

Uji hipotesis dalam penelitian ini menggunakan : a. Persamaan regresi linier berganda yang berguna untuk menganalisis hubungan linier antara 2 variabel independen atau lebih dengan 1 variabel dependen. Penelitian ini menggunakan persamaan regresi linier berganda dengan 2 variabel independen, yaitu:

$\mathrm{Y}=\mathrm{a}+\mathrm{b}_{1} \mathrm{X}_{1}+\mathrm{b}_{2} \mathrm{X}_{2}$

Keterangan : $\mathrm{Y}=$ Pemilihan Karier sebagai Akuntan Pubik, a = Konstanta, $\mathrm{b}_{1}, \mathrm{~b}_{2},=$ Koefisien Regresi, $\mathrm{X}_{1}=$ Undang-undang Akuntan Publik dan $\mathrm{X}_{2}$ = Etika Profesi Akuntan Publik.

b. Uji Parsial atau uji $\mathrm{t}$ adalah pengujian signifikansi untuk mengetahui pengaruh variabel $\mathrm{X}_{1}$ dan $\mathrm{X}_{2}$ terhadap $\mathrm{Y}$ secara parsial, apakah berpengaruh signifikan atau tidak. Adapun kriteria pengujiannya adalah :

- Jika - $\mathrm{t}$ tabel $\leq \mathrm{t}$ hitung $\leq \mathrm{t}$ tabel, maka Ha ditolak.

- Jika -t hitung < - t tabel atau t hitung $>\mathrm{t}$ tabel, maka Ha diterima.

Dasar signifikansinya adalah :

- Jika signifikansi > 0,05, maka Ha ditolak.

- Jika signifikansi $<0,05$, maka Ha diterima.

c. Uji simultan atau uji F. Analisis varian (ANOVA) merupakan uji koefisien regresi secara simultan (uji F) untuk menguji signifikansi pengaruh beberapa variabel independen terhadap variabel dependen. Peran ANOVA adalah untuk menguji signifikansi pengaruh pemahaman mengenai undang-undang dan etika profesi akuntan publik terhadap pemilihan karier sebagai akuntan publik. Pengujian menggunakan tingkat signifikansi 0,05 . Adapun kriteria pengujiannya adalah :

- Jika F hitung $\leq \mathrm{F}$ tabel, maka Ha ditolak.

- Jika F hitung > F tabel, maka Ha diterima.

d. Uji Koefisien Determinasi

Uji koefisien determinasi untuk mengukur seberapa jauh kemampuan variabel independen dalam menerangkan variabel dependen. Nilai 
Pemahaman Mengenai Undang-Undang Dan Etika Profesi Akuntan Publik Terhadap Pemilihan Karier Sebagai Akuntan Publik

koefisien determinasi dilihat dari nilai $\mathrm{R}$ dan Adjusted R Square karena dalam penelitian ini menggunakan regresi linier berganda dengan 2 variabel independen dan angka pada Adjusted $\mathrm{R}$ Square untuk mengetahui seberapa besar sumbangan pengaruh variabel independen terhadap variabel independen.

\section{HASIL DAN PEMBAHASAN Uji Validitas dan Uji Reliabilitas}

Hasil uji validitasnya adalah untuk pertanyaan undang-undang akuntan publik ada 10 pertanyaan yang valid, etika profesi akuntan publik ada 16 pertanyaan yang valid dan pemilihan karier sebagai akuntan publik ada 15 pertanyaan yang valid, nilai hasil uji tersebut setelah dibandingkan dengan hasil perhitungan $r$ tabel $=0,220$ sehingga diperoleh $r$ hitung diatas $r$ tabel dan item pertanyaannya valid. Hasil uji reliabel, nilai cronbach's alpha dari keempat variabel menunjukkan nilai lebih dari 0,80 sehingga item pertanyaan baik dan reliabel.

\section{Uji Normalitas}

Uji normalitas bahwa signifikansi undangundang akuntan publik sebesar 0,051 untuk etika profesi akuntan publik signifikansinya adalah 0,053 dan pemilihan karier sebagai akuntan publik nilai signifikansinya 0,059 maka disimpulkan bahwa ketiga variabel tersebut terdistribusi normal karena nilai signifikansi > 0,05 .

\section{Uji Multikolinearitas}

Uji multikolinearitas, hasil analisis dapat diketahui masing-masing variabel independen nilai tolerance 0,846 dan VIF 1,183 maka disimpulkan tidak terjadi multikolinearitas karena tolerance lebih dari 0,10 dan VIF kurang dari 10.

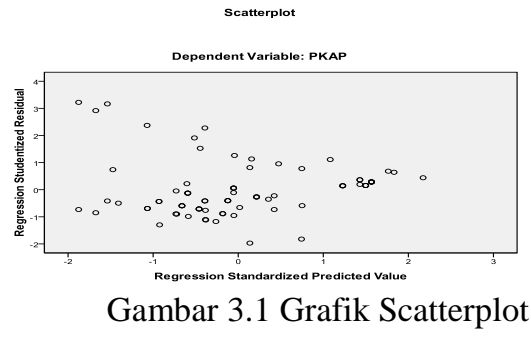

\section{Uji Heteroskedastisitas}

Uji heteroskedastisitas pada output Scatterplot pada gambar 3.1 dapat diketahui bahwa titik-titik tidak membentuk pola yang jelas (bergelombang, melebar, kemudian menyempit). Titik-titik menyebar diatas dan dibawah 0 pada sumbu Y. Jadi disimpulkan bahwa analisis dalam pengujian ini tidak terjadi heteroskedastisitas, sehingga model regresi ini layak dipakai untuk memprediksi pemilihan karier sebagai akuntan publik berdasarkan masukan variabel independen dari undang-undang akuntan publik dan etika profesi akuntan publik.

\section{Uji Autokorelasi}

Uji autokorelasi, bahwa nilai DW adalah 1,805. Untuk dL dan dU yang dilihat dari DW tabel pada signifikansi 0,05 dengan $\mathrm{n}$ (jumlah data) 80 dan $\mathrm{k}$ (jumlah variabel independen) $=2$, didapat nilai dL adalah 1,585 dan $\mathrm{dU}$ adalah 1,688. Jadi nilai 4-dU(4-1,688) $=2,312$ dan 4-dL $(4-1,585)=2,415$. Hal ini berarti nilai DW terletak antara dU dan 4-dU, yaitu 1,805 terletak antara 1,688 dan 2,312 sehingga kesimpulannya tidak ada autokorelasi.

\begin{tabular}{|c|c|c|c|}
\hline \multicolumn{4}{|c|}{$\begin{array}{c}\text { Tabel 3.1 } \\
\text { Hasil Analisis Regresi berganda }\end{array}$} \\
\hline \multirow{2}{*}{ Model } & \multicolumn{2}{|c|}{$\begin{array}{l}\text { Unstandardized } \\
\text { Coefficients }\end{array}$} & \multirow{2}{*}{$\begin{array}{c}\begin{array}{c}\text { Standardized } \\
\text { Coefficients }\end{array} \\
\text { Beta }\end{array}$} \\
\hline & B & $\begin{array}{l}\text { Std. } \\
\text { Error }\end{array}$ & \\
\hline (Constant) & -17.903 & 8,752 & \\
\hline UUAP & 0,706 & 0,197 & .383 \\
\hline EPAP & 0,239 & 0,117 & .219 \\
\hline
\end{tabular}

\section{Persamaan Regresi Linier}

Persamaan linier berganda sebagai berikut $: \mathrm{Y}=17,903+0,706 \mathrm{X}_{1}+0,239 \mathrm{X}_{2}+\mathrm{e}$, Arti dari angka-angka dalam persamaan diatas adalah sebagai berikut :

1) Nilai konstanta (a) adalah 17,903 artinya jika undang-undang akuntan publik dan etika profesi akuntan publik bernilai 0, maka pemilihan karier sebagai akuntan publik bernilai positif $(17,903)$.

2) Nilai koefisien regresi variabel undang-undang akuntan publik $\left(b_{1}\right)$ bernilai positif yaitu 0,706 artinya setiap pemahaman undang-undang akuntan publik sebesar 1 akan meningkatkan pemilihan karier sebagai akuntan publik sebesar 0,706 dengan asumsi variabel lain bernilai tetap. 
Pemahaman Mengenai Undang-Undang Dan Etika Profesi Akuntan Publik Terhadap Pemilihan Karier Sebagai Akuntan Publik

3) Nilai koefisien regresi variabel etika profesi akuntan publik $\left(\mathrm{b}_{2}\right)$ bernilai positif yaitu 0,239 artinya setiap pemahaman etika profesi akuntan publik sebesar 1 akan meningkatkan juga pemilihan karier sebagai akuntan publik sebesar 0,239 dengan asumsi variabel lain nilainya tetap.

\section{Uji t}

Uji Parsial atau Uji t, Untuk penentuan $t$ tabel dalam tabel statistik pada signifikansi 0,05 / $2=0,025$ dengan derajat kebebasan $\mathrm{df}=\mathrm{n}-\mathrm{k}-1$ atau $37-2-1=34$, hasil yang diperoleh pada $t$ tabel $-2,032$.

\begin{tabular}{lcc} 
& $\begin{array}{c}\text { Tabel 3.2 } \\
\text { Hasil Uji t }\end{array}$ \\
\hline Variabel Independen & $\mathbf{t}$ & Sig. \\
\hline Pajak Hotel & 3,591 & 0,001 \\
Pajak Restoran & 2,054 & 0,043 \\
\hline Sumber : Olah data Penulis, 2015. &
\end{tabular}

Hipotesis 1 : Pengujian variabel pemahaman mengenai undang-undang akuntan publik $\left(\mathrm{X}_{1}\right)$ Merumuskan Hipotesis :

$\mathrm{H}_{\mathrm{o}}$ : Pemahaman mengenai undang-undang akuntan publik tidak berpengaruh terhadap pemilihan karier sebagai akuntan publik.

$\mathrm{H}_{1}$ : Pemahaman mengenai undang-undang akuntan publik berpengaruh terhadap pemilihan karier sebagai akuntan publik.

Pada tabel 3.2, bahwa t hitung sebesar 3,591. Jadi $\mathrm{t}$ hitung > t tabel $(3,591>1,991)$, makaH $_{\mathrm{a}}$

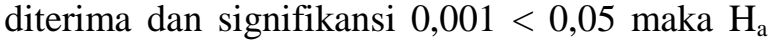
diterima, sehingga hasilnya bahwa pemahaman mengenai undang-undang akuntan publik berpengaruh terhadap pamilihan karier sebagai akuntan publik.

Hipotesis 2 : Pengujian variabel pemahaman akuntansi mengenai Etika Profesi Akuntan Publik $\left(\mathrm{X}_{2}\right)$

Merumuskan Hipotesis :

$\mathrm{H}_{\mathrm{o}}$ : Pemahaman mengenai etika profesi akuntan publik tidak berpengaruh terhadap pemilihan karier sebagai akuntan publik.

$\mathrm{H}_{2}$ : Pemahaman mengenai etika profesi akuntan publik berpengaruh terhadap pemilihan karier sebagai akuntan publik.

Pada tabel 3.2 diatas, bahwa t hitung sebesar 2,054 . Jadi $t$ hitung $>\mathrm{t}$ tabel $(2,054>1,991)$, maka $\mathrm{H}_{\mathrm{a}}$ diterima dan signifikansi $0,043<0,05$ maka $\mathrm{H}_{\mathrm{a}}$ diterima, sehingga hasilnya bahwa pemahaman mengenai etika profesi akuntan publik berpengaruh terhadap pamilihan karier sebagai akuntan publik.

\section{Uji F}

Uji Simultan atau Uji F, perumusan hipotesisnya adalah :

$\mathrm{H}_{\mathrm{o}}$ : Pemahaman mengenai undang-undang dan etika profesi akuntan publik secara simultan tidak berpengaruh terhadap pemilihan karier sebagai akuntan publik.

$\mathrm{H}_{3}$ : Pemahaman mengenai undang-undang dan etika profesi akuntan publik secara simultan berpengaruh terhadap pemilihan karier sebagai akuntan publik.

\begin{tabular}{cccc}
\multicolumn{4}{c}{ Tabel 3.3} \\
& Hasil Uji F & \\
\hline F Hitung & Sig & F Tabel & Keterangan \\
\hline 3,437 & 0,000 & 13,543 & Ha Diterima \\
\hline Sumber : Olah data penulis, 2015 &
\end{tabular}

Nilai F tabel pada tabel statistik pada tingkat signifikansi 0,000 dengan df 1 (jumlah variabel $1=2$ dan df $2(n-k-1)$ atau 80-2-1 = 77, diperoleh $\mathrm{F}$ tabel sebesar 3,115. Analisis penulis pada tabel 3.3 diketahui $\mathrm{F}$ hitung sebesar 13,543 dan signifikansi 0,000. Kesimpulannya $\mathrm{F}$ hitung $>\mathrm{F}$ tabel $(13,543>3,115)$ dan signifikansinya $<0,05$ $(0,000<0,05)$ maka $\mathrm{H}_{\mathrm{a}}$ diterima, sehingga diperoleh hasil $\mathrm{H}_{3}$ bahwa pemahaman mengenai undang-undang dan etika profesi akuntan publik secara simultan berpengaruh terhadap pemilihan karier sebagai akuntan publik.

Tabel 3.4

\begin{tabular}{cccc}
\multicolumn{4}{c}{ Koefisien Determinasi } \\
\hline $\mathrm{R}$ & $\begin{array}{c}\mathrm{R} \\
\text { Square }\end{array}$ & $\begin{array}{c}\text { Adjusted } \mathrm{R} \\
\text { Square }\end{array}$ & $\begin{array}{c}\text { Standard Error } \\
\text { of the Estimate }\end{array}$ \\
\hline 0,510 & 0,260 & 0,241 & 5,992 \\
\hline Sumber : Olah data Penulis, 2015. &
\end{tabular}

\section{Uji Determinasi}

Uji koefisien determinasi untuk mengukur seberapa jauh kemampuan variabel independen dalam menerangkan variabel dependen. Pada tabel 3.4 diperoleh Adjusted R Square sebesar 0,241 artinya persentase sumbangan pengaruh variabel pemahaman mengenai undang-undang dan etika profesi akuntan publik terhadap pemilihan karier sebagai akuntan publik sebesar $24,1 \%$ sedangkan sisanya sebesar $75,9 \%$ dipengaruhi variabel lain yang tidak digunakan dalam penelitian ini. 
Pemahaman Mengenai Undang-Undang Dan Etika Profesi Akuntan Publik Terhadap Pemilihan Karier Sebagai Akuntan Publik

\section{PEMBAHASAN}

Berdasarkan pengujian uji $\mathrm{t}$ dihasilkan untuk $\mathrm{H}_{1}$ hasilnya $\mathrm{t}$ hitung $>\mathrm{t}$ tabel $(3,591>$ 1,991), dan signifikansi $0,001<0,05$ maka $\mathrm{H}_{\mathrm{a}}$ diterima, sehingga pemahaman mengenai undang-undang akuntan publik berpengaruh terhadap pamilihan karier sebagai akuntan publik. $\mathrm{H}_{2}$ hasilnya t hitung > t tabel $(2,054>$ 1,991), dan signifikansi $0,043<0,05{\text { maka } \mathrm{H}_{\mathrm{a}}}$ diterima, sehingga pemahaman mengenai etika profesi akuntan publik berpengaruh terhadap pemilihan karier sebagai akuntan publik. Uji F, F hitung > F tabel $(13,543>3,115)$ dan signifikansinya $<0,05(0,000<0,05)$ maka Ha diterima sehingga $\mathrm{H}_{3}$ hasilnya bahwa pemahaman mengenai undang-undang dan etika profesi akuntan publik secara simultan berpengaruh terhadap pemilihan karier sebagai akuntan publik.

Perbandingan penelitan sebelumnya yaitu, penelitian Adek Fajar Agustini DS, 2010 dengan judul "Anlisis Faktor-Faktor Yang Mempengaruhi Mahasiswa Akuntansi Di Universitas Pembangunan Nasional Veteran Jatim dalam Pemilihan Profesi Sebagai Akuntan Publik", berdasarkan hasil analisis regresi logistik menunjukkan bahwa hipotesis ke-1 yang menyatakan "Bahwa faktor nilai intrinsik pekerjaan, gaji, pertimbangan pasar kerja dan persepsi mahasiswa akuntansi tentang profesi akuntan publik berpengaruh terhadap pemilihan profesi akuntan publik bagi mahasiswa akuntansi Universitas Pembangunan Nasional "Veteran" Jawa Timur" tidak teruji kebenarannya. Hipotsis ke-2 yang menyatakan "Bahwa faktor persepsi mahasiswa akuntansi tentang profesi akuntan publik merupakan faktor yang paling dominan berpengaruh terhadap pemilihan profesi akuntan publik bagi mahasiswa akuntansi Universitas Pembangunan Nasional "Veteran" Jawa Timur" tidak teruji kebenarannya.

Andreas Sofyan Nainggolan, 2013 dalam judul "Pengaruh Persepsi Mahasiswa Akuntansi Mengenai Undang-Undang Akuntan Publik Dan Etika Profesi Akuntan Publik Terhadap Persepsi Mengenai Pilihan Kariernya Sebagai Akuntan Publik". Berdasarkan hasil pengujian hipotesis dengan menggunakan uji t untuk parsial dan uji $F$ untuk simultan menunjukkan bahwa ada pengaruh persepsi mahasiswa akuntansi tentang
Undang-Undang Akuntan Publik dan Etika Profesi Akuntan Publik terhadap persepsi mengenai pilihan kariernya sebagai Akuntan Publik baik secara parsial maupun simultan.

Muthia Corawettoeng, 2013 dengan judul "Pengaruh Persepsi Mahasiswa Akuntansi Mengenai Lingkungan Kerja Auditor Terhadap Pilihan Kariernya Sebagai Auditor (Studi Pada Mahasiswa Akuntansi Universitas Hasanudin dan Politehnik Negeri Ujung Pandang)". Dengan hasil pengujian uji t menunjukkan bahwa persepsi mahasiswa akuntansi mengenai lingkungan kerja auditor memiliki pengaruh terhadap pilihan karier sebagai auditor. Dengan demikian penelitian ini hasilnya sama dengan Andreas Sofyan Nainggoaln dan Muthia Corawettoeng yang hipotesisnya sama-sama tercapai, jadi pemahaman tentang UndangUndang akuntan publik dan pemahaman tentang etika profesi akuntan publik harus benar-benar di kuasai setiap mahasiswa jika mereka ingin berprofesi sebagai akuntan publik.

\section{KESIMPULAN}

Penelitian ini tujuannya untuk mengetahui secara parsial dan simultan pengaruh pemahaman mengenai undangundang dan etika profesi akuntan publik terhadap pemilihan karier sebagai akuntan publik. Jenis penelitian adalah deskriptif kualitatif. Sumber data adalah data primer. Populasi, sampel dan responden adalah para mahasiswa akuntansi UNIBA Surakarta, pengambilan sampel dengan random sampling. Instrumen penelitian menggunakan kuesioner yang di uji validitas dan reliabilitas. Metode analisis data yang digunakan uji deskriptif, uji asumsi klasik meliputi uji normalitas, uji multikolinearitas, uji heteroskedastisitas, uji autokorelasi untuk uji hipotesis menggunakan regresi linier berganda dengan uji t, uji $F$ dan uji determiasi $\left(\mathrm{R}^{2}\right) . \mathrm{H}_{1}$ hasilnya $\mathrm{t}$ hitung $>\mathrm{t}$ tabel $(3,591>1,991)$, dan signifikansi $0,001<0,05$ maka $\mathrm{H}_{\mathrm{a}}$ diterima, sehingga pemahaman mengenai undang-undang akuntan publik berpengaruh terhadap pemilihan karier sebagai akuntan publik. $\mathrm{H}_{2}$ hasilnya $\mathrm{t}$ hitung $>\mathrm{t}$ tabel $(2,054>1,991)$, dan signifikansi $0,043<0,05$ 
Pemahaman Mengenai Undang-Undang Dan Etika Profesi Akuntan Publik Terhadap Pemilihan Karier Sebagai Akuntan Publik

maka $\mathrm{H}_{\mathrm{a}}$ diterima, sehingga pemahaman mengenai etika profesi akuntan publik berpengaruh terhadap pemilihan karier sebagai akuntan publik. Uji F, F hitung > F tabel $(13,543$ $>3,115)$ dan signifikansinya $<0,05(0,000<$ 0,05) maka Ha diterima sehingga $\mathrm{H}_{3}$ hasilnya bahwa pemahaman mengenai undang-undang dan etika profesi akuntan publik secara simultan berpengaruh terhadap pemilihan karier sebagai akuntan publik.

\section{KETERBATASAN PENELITIAN}

Dalam penelitian ini terdapat beberapa keterbatasan antara lain :

1. Penelitian ini hanya menguji dua variabel independen yaitu pemahaman mahasiswa akuntansi mengenai undang-undang akuntan publik dan pemahaman mahasiswa akuntansi mengenai etika profesi akuntan publik.

2. Penelitian yang hanya menggunakan kuesioner sehingga masih ada kemungkinan kelemahan-kelemahan yang ditemui, seperti jawaban yang kurang cermat, responden yang menjawab asal-asalan dan tidak jujur, serta pertanyaan yang kurang lengkap atau kurang dipahami oleh responden.

3. Data dikumpulkan dengan menggunakan kuesioner dan diisi berdasarkan waktu luang yang dimiliki oleh para mahasiswa kondisi ini kemungkinan menimbulkan lemahnya kontrol terhadap teknik pengisian kuesioner.

\section{SARAN}

Saran kepada peneliti selanjutnya sebagai bahan pertimbangan, yaitu :

1. Penelitian ini bisa dijadikan referensi dan bahan pertimbangan peneliti selanjutnya dengan penambahan variabel independen yang berbeda dalam mempengaruhi pemilihan karier sebagai akuntan publik.

2. Penelitian kedepan diharapkan tidak hanya dengan kuesioner tetapi bisa dengan wawancara langsung kepada mahasiswa.

3. Disarankan kuesioner bisa dibacakan peneliti dengan wawancara langsung sehingga bisa mengumpulkan data yang akurat.
ISSN : 2477-6157

\section{DAFTAR PUSTAKA}

Absara, Lara. 2011. Faktor-faktor Yang Mempengaruhi Mahasiswa Akuntansi Dalam Pemilihan Karir Menjadi Akuntan Publik. Skripsi tidak diterbitkan. Semarang: Fakultas Ekonomi Universitas Dipanegara.

Corawettoeng, Muthia. 2013. "Pengaruh Persepsi Mahasiswa Akuntansi Mengenai Lingkungan Kerja Auditor Terhadap Pilihan Sebagai Auditor (Studi Pada Mahasiswa Akuntansi Universitas Hasanudin dan Politehnik Negeri Ujung Pandang) '.Universitas Hasanuddin. Skripsi.

Fajar Agustini DS, Adek. 2010.“Analisis FaktorFaktor Yang Mempengaruhi Mahasiswa Akuntansi Nasional Veteran Jatim Dalam Pemilihan Profesi Sebagai Akuntan Publik". UPN Jawa Timur. Thesis.

Fakultas Ekonomi Universitas Islam Batik Surakarta, Jurusan Akuntansi. 2014. Panduan Penulisan Skripsi. Surakarta.

Kamisa, 1989. Kamus Besar Bahasa Indonesia. Jakarta: Kartika.

Mulyadi, 2002. Auditing. Edisi 6. Jakarta : Salemba Empat.

Nurlan, Andi Besse. 2011. Persepsi Akuntan dan Mahasiswa Jurusan Akuntansi Terhadap Kode Etik Ikatan Akuntan Indonesia. Skripsi tidak diterbitkan. Makassar: Fakultas Ekonomi Universitas Hasanuddin.

Priyatno, Duwi. 2009. 5 Jam Belajar Olah Data dengan SPSS 17. Yogyakarta. Andi Offset.

Rasmini, Ni Ketut. 2007. Faktor-Faktor yang Berpengaruh pada Keputusan Pemilihan Profesi Akuntansi Mengenai Faktor-Faktor yang Mempengaruhi Pemilihan Karier. 
Pemahaman Mengenai Undang-Undang Dan Etika Profesi Akuntan Publik Terhadap Pemilihan Karier Sebagai Akuntan Publik

Simposium Nasional Akuntansi VI, Surabaya, 16-17 Oktober : 821-829.72

Sekaran, Uma. 2006. Metedologi Penelitian untuk Bisnis. Edisi 4. Jakarta : Salemba Empat.

Sofyan Nainggolan, Andreas. 2013. "Pengaruh Persepsi Mahasiswa Akuntansi Mengenai Undang-Undang Akuntan Publik dan Etika Profesi Akuntan Publik Terhadap Persepsi Mengenai Pilihan Kariernya Sebagai Akuntan Publik". Universitas Negeri Semarang. Skripsi.

Sumarna, Agus. (2002). Sarjana Akuntansi \& Potensi yang Perlu di Gali. Media Akuntansi 30.Edisi Desember 2002-Januari 2013 : Hal: 17-20.

Undang-Undang Republik Indonesia Nomor 5 Tahun 2011 Tentang Akuntan Publik. 2011. (https://faizzamzami.wordpress.com/2011/1 0/24/undang-undang-nomor-5-tahun-2011tentang-akuntan-publik/. Di posting : 24 oktober 2011. Pukul : 3.12 AM.

Widyasari. 2013. "Faktor-Faktor Pemilihan Profesi Akuntan". (https://dianpawpaw.wordpress.com/tag/aku ntan-publik). Diposting : 1 September 2013. 